\title{
Evaluation of introduced plum varieties under extreme climatic conditions
}

\author{
Surányi, D. \\ NARIC Fruit Research Station, Cegléd \\ suranyi.dezso@cefrucht.hu
}

Summary: In the gene bank variety collection, 15 plum varieties were examined based on morphogenetic and pomological traits. Most cultivars of self-fertilizing or pollinating partners were well-cultivated. In addition to Queston, Stanley, Valor and Verity, towards 11 new cultivars have been experienced in this paper. From the observations, it seems that the growth and plantation of Valor, Presenta, Topfive and Bellamira can increase. However, the Top Sugar and Valor fruit sizes are best suited to market requirements. The role of Stanley may be reduced, but there is no reason to replace it. However, the questions of local varieties of domestic origin fall into a different category, and raw materials for quality products are difficult to replace with other varieties.

Surányi, D. (2019): Evaluation of introduced plum varieties under extreme climatic conditions. International Journal of Horticultural Science 25(1-2): 7-10. https://doi.org/10.31421/IJHS/25/1-2./2698

Key words: plum varieties, extreme climatic conditions, morphogenetical traits, pomological valuabilty

\section{Introduction}

Plum growing in Hungary has been in crisis because it did not receive the support it deserved and required for the improvement of native varieties and, in general, breeding work. The fertility and content values of the plum Besztercei szilva could not replace the demands of marketability, and the problems of the subject matter and the sharka sensitivity of the varieties overcame the problems.

After the 180-year-old Hungarian plum variety, the dominance of Stanley, then the Čačak and partly the Romanian cultivars appeared. At present, the new German-bred varieties are being introduced, and in all other cases, it will be necessary to look carefully for the few varieties that correspond to the Hungarian eco-geographic conditions, cultivation, consumption and market culture.

Of course, neither the varieties of the old breed collections nor the new varieties of the present ones should be susceptible to plum cultivation. The present study seeks to carefully establish the introduction of new varieties and, in justified cases, to disseminate suitable cultivars. Recently, it can be observed that variety composition is also supported by domestic and foreign nurseries, but we cannot ignore wellfounded and prudent research.

The impatience of producers is legitimate, but the lack of financial resources and expectations for research leave a disproportionate burden on the breeder's shoulder. The economic policy of the 1960 s plummeting up to now has an impact on the competitiveness of Hungarian plum cultivation. Stanley is currently also a leading breed, but the varieties of

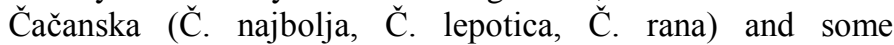
Romanian varieties (Silvia, Tuleu gras etc.) are also grown (Surányi, 2006). The role of historical and local varieties is diminishing, but is still dominant in organic production. After 1990, new perspective cultivars of German breeding centers
(Stuttgart-Hohenheim, Geisenheim) were examined at the Department of Fruit Plants of the University of Horticulture at Budapest.

Kovács and his colleagues (Molnár et al., 2014, 2016) carry out pomological evaluation of German breeds, and then joined Nádosy (2016), who started grating the nurseries and recently became rootstock effects to their research. Makovics-Zsohár et al. (2017) was involved in introducing and Hungarian local varieties researched the molecular genetic profile.

The standard cultivars and the new German varieties were not retained from the plum collections introduced after 2002, making Queston, Stanley, Valor and Verity a comparison base. Several methods of gene bank breeding were used, most notably the morphogenetic evaluations developed decades ago (Surányi 1976, 1985, 1991, quoted by Faust 1989). The climatic differences between the country's plum-producing areas and other breeding sites in Germany require multidisciplinary research to find Stanley varieties and complementary varieties.

\section{Materials and methods}

In 2002-2003, we planted on type C 679 myrobalan seedling rootstock plum varieties at Cegléd, the Research Institute. 5-5 individuals of each cultivar were included in the observations, which were placed in the order of ripening. Location of varieties was in the plantation: Katinka, Top sugar Topfive, Miragrande, Bellamira, Verity, Valor, Topking, Queston, Jojo, Stanley, Presenta, Tophit, Topper and Elena.

From the spring of 2004, at the beginning of full bloom, 3030 flowers harvested from herbivores were used to determine the length of the pistil, the stamen number per flower, and then 
the relative stamen number was calculated (Surányi, 1976). Morphogenetic data were also statistically analyzed. On each of the two individuals, about 100-120 left-side branches were assigned to the flowering flower number and 8 weeks later the value obtained from open pollination was obtained on the basis of the fruit beginnings. After recording the most flowering and maturing date (the interval in the study), between 2004 and 2009 we determined the mean weight of the fruit of 30 fruits (Surányi, 1991).

For the climatic characterization of the area of the plantation we determined the average annual temperature, the annual precipitation amount, the average temperature of the blossoming month and the flowering period in September (Surányi, 1985).

\section{Results and discussion}

From the start of the plantation, climate change is clearly visible on the basis of the average annual temperature. In 2007 and 2008 the average temperature approached the average of many years (1950-1990), the average temperature in April was higher than usual, which meant drought. However, the annual amount of precipitation in 2004 and 2008 exceeded the average. According to our observations, dry and warm April resulted in rapid flowering and weaker fruit setting (Table 1). In the 22-year study period (cf. Surányi, 2009), we could not show any negative effects in the flower induction month in September. In the past, we found abnormal flowers among the collections of varieties, and only a few of the 15 plum varieties found apistile and policarpic gynoecium or staminods, sterile anthers etc.

Table 1. Changing of climatic factors during traits

\begin{tabular}{|c|c|c|c|c|}
\hline \multirow{2}{*}{ Years } & \multicolumn{3}{|c|}{ Average temperature $\left({ }^{\circ} \mathbf{C}\right)$} & $\begin{array}{c}\text { Annual } \\
\text { rainfall (mm) }\end{array}$ \\
\cline { 2 - 5 } & Annual & April & September & \\
\hline 2002 & 11.3 & 11.2 & 16.2 & 559.4 \\
\hline 2003 & 11.4 & 10.5 & 17.2 & 442.2 \\
\hline 2004 & 11.1 & 12.6 & 16.4 & 600.6 \\
\hline 2005 & 12.5 & 12.2 & 16.6 & 487.8 \\
\hline 2006 & 12.4 & 12.3 & 14.8 & 434.3 \\
\hline 2007 & 10.6 & 12.6 & 18.4 & 442.5 \\
\hline 2008 & 10.8 & 12.9 & 17.3 & 604.9 \\
\hline 2009 & 12.2 & 15 & 19.7 & 523.8 \\
\hline Mean & $\mathbf{1 3 . 5 2}$ & $\mathbf{1 2 . 4}$ & $\mathbf{1 7 . 0 6}$ & $\mathbf{5 1 1 . 9 3}$ \\
\hline
\end{tabular}

Due to the rapid and urgent changes of the plums, the variety descriptions and the breed change are based on practical pomological characteristics. Morphogenetic traits include data on self-fertility and open pollination, but many flowers have rarely been evaluated for their formal properties (Table 2). However, the analyzes carried out in Cegléd and Érd on Tóth $(1957,1969)$ would be necessary not only for better knowledge of the varieties and for more efficient breeding work.

In the observed years the varieties were $11.8-14.7 \mathrm{~mm}$ in size, Miragrande and Valor (self-sterile plums) were characterized by shorter pistils; similarly, the number of stamens and relative stamen numbers of the varieties also changed. The fertility values obtained from open flowering always fell between $12 \%$ and $32 \%$ (Table 2). Following the announcement of Nádosy (2016), it is not surprising that the parents of the new varieties were almost identical, which was confirmed by molecular genetic analyzes (Makovics-Zsohár et al., 2017). The value of open fertilization, together with the average fruit weight, significantly influences the cultivation of varieties. However, with the Prunus syriaca parent, Bellamira and Miragrande produced high yields because of their relatively high cropping area (Table 3).

Table 2. Comparative studies of morphogenetical traits (2004-2007)

\begin{tabular}{|l|c|c|c|c|}
\hline Cultivar & $\begin{array}{c}\text { Pistil length } \\
(\mathbf{m m})\end{array}$ & $\begin{array}{c}\text { Stamen } \\
\text { number } \\
(\mathbf{n o})\end{array}$ & $\begin{array}{c}\text { Relative } \\
\text { stamen } \\
\text { number, } \\
\text { no./mm }\end{array}$ & $\begin{array}{c}\text { Open } \\
\text { pollination } \\
(\boldsymbol{\%})\end{array}$ \\
\hline Bellamira & 11.8 & 28.2 & 2.31 & 12.1 \\
\hline Elena & 13.1 & 24.7 & 1.90 & 21.4 \\
\hline Jojo & 12.7 & 25.3 & 1.98 & 25.3 \\
\hline Katinka & 13.0 & 28.5 & 2.16 & 28.1 \\
\hline Miragrande & 12.6 & 26.9 & 2.12 & 31.1 \\
\hline Presenta & 12.9 & 26.3 & 2.05 & 19.4 \\
\hline Queston & 10.7 & 26.5 & 2.48 & 16.9 \\
\hline Stanley & 14.8 & 27.1 & 1.83 & 26.7 \\
\hline Top sugar & 13.7 & 25.2 & 1.38 & 17.0 \\
\hline Topfive & 14.2 & 27.1 & 1.92 & 18.8 \\
\hline Tophit & 13.8 & 26.0 & 1.84 & 24.7 \\
\hline Topking & 14.7 & 27.6 & 1.91 & 17.9 \\
\hline Topper & 14.1 & 26.9 & 1.93 & 12.6 \\
\hline Valor & 12.8 & 27.1 & 1.89 & 19.3 \\
\hline Verity & 12.8 & 24.3 & 1.87 & 19.5 \\
\hline LSD 5 \% & 0.81 & 2.13 & 0.212 & 3.88 \\
\hline
\end{tabular}

Table 3. Pomological valuabilty of introduced plums (2004-2009)

\begin{tabular}{|l|c|c|c|c|}
\hline \multicolumn{1}{|c|}{ Cultivar } & Most blooms & Ripening time & $\begin{array}{c}\text { Yield } \\
\text { (kg/tree) }\end{array}$ & $\begin{array}{c}\text { Fruit } \\
\text { weight }(\mathbf{g})\end{array}$ \\
\hline Bellamira & $04.10-15.04$ & $20.08-09.09$ & 32.3 & $25-29$ \\
\hline Elena & $04.07-13.04$ & $13.09-17.09$ & 28.2 & $26-29$ \\
\hline Jojo & $04.02-06.04$ & $28.08-07.09$ & 26.9 & $31-35$ \\
\hline Katinka & $04.06-10.04$ & $21.07-10.08$ & 37.5 & $29-32$ \\
\hline Miragrande & $04.13-16.04$ & $14.08-17.08$ & 34.4 & $17-20$ \\
\hline Presenta & $04.04-12.04$ & $01.09-08.09$ & 28.8 & $29-31$ \\
\hline Queston & $04.08-13.04$ & $18.08-25.08$ & 26.7 & $34-38$ \\
\hline Stanley & $04.07-13.04$ & $28.08-08.09$ & 32.2 & $36-40$ \\
\hline Top sugar & $04.10-14.04$ & $24.08-02.09$ & 23.3 & $40-44$ \\
\hline Topfive & $04.12-17.04$ & $10.08-16.08$ & 36.5 & $31-35$ \\
\hline Tophit & $04.10-14.04$ & $01.09-14.09$ & 30.1 & $50-59$ \\
\hline Topking & $04.10-14.04$ & $23.08-02.09$ & 28.6 & $38-40$ \\
\hline Topper & $04.12-14.04$ & $02.09-17.09$ & 27.9 & $28-32$ \\
\hline Valor & $04.12-16.04$ & $23.08-31.08$ & 30.7 & $46-52$ \\
\hline Verity & $04.08-13.04$ & $21.08-27.08$ & 31.4 & $35-38$ \\
\hline Mean & 11.04 & 30.08 & $\mathbf{2 9 . 6 9}$ & $\mathbf{3 4 . 9 7}$ \\
\hline
\end{tabular}




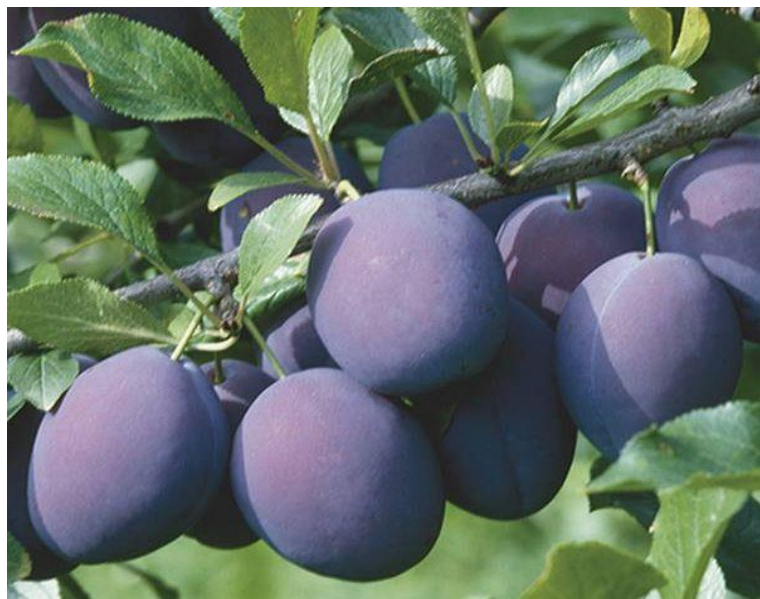

Figure 1: Plum cultivar of Valor

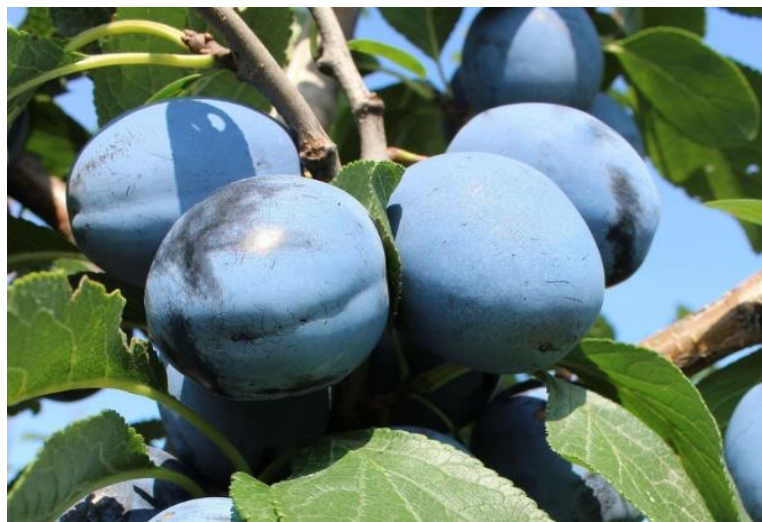

Figure 3: Plum cultivar of Topfive

The main bloom of the German plum cultivars in Cegléd falls on the 100th day of the year, with Jojo, Katinka and Elena flourishing, to some extent with Verity. As the main flowering period coincides with the self-sterile (Miragrande, Valor) and partially self-fertile (Queston, Top sugar, Topfive, Tophit, Topking and Verity) varieties, higher fruit set is ensured. At the time of ripening, the cultivars showed stability in the successive years, what we can explain with their genetic stability and midAugust weather (Figure 1-4). The average ripening time of the examined plum cultivars fell from 30 to 31 August 2002-2009. The examinations of Molnár et al. (2014, 2016) and Nádosy (2016) are similar, but somewhat earlier than in StuttgartHohenheim and Geisenheim (Artevos and Omafra).

In a traditional tatura and cultivation system, the harvest of 6 to 10 -year-old plum trees is $25-50 \mathrm{~kg} /$ tree; for the Top Sugar and Valor varieties, the average weight of the other varieties was lower (Table 3). Not surprisingly, there was no way to irrigate plum varieties, and the lack of fruit at the end of July and August did not help. In 2007, the desert warm were littered with trees, but only leaf-scorching occurred - damaging the fruits of Bellamira. The fruits of Miragrande were better protected by leaves, and no sunburns were observed in blue plums until 2009.

The perspective of domesticated varieties can be evaluated in modern cultivation forms, subjects for intensive forms and irrigation in plantations. Still, it can be stated that the Čačak, Romanian and German varieties can ensure the recovery of Hungarian plum growing. However, selection as a breeding method for domestic gene material should be retained, especially for the enhancement of sharka resistant or at least tolerant individuals.

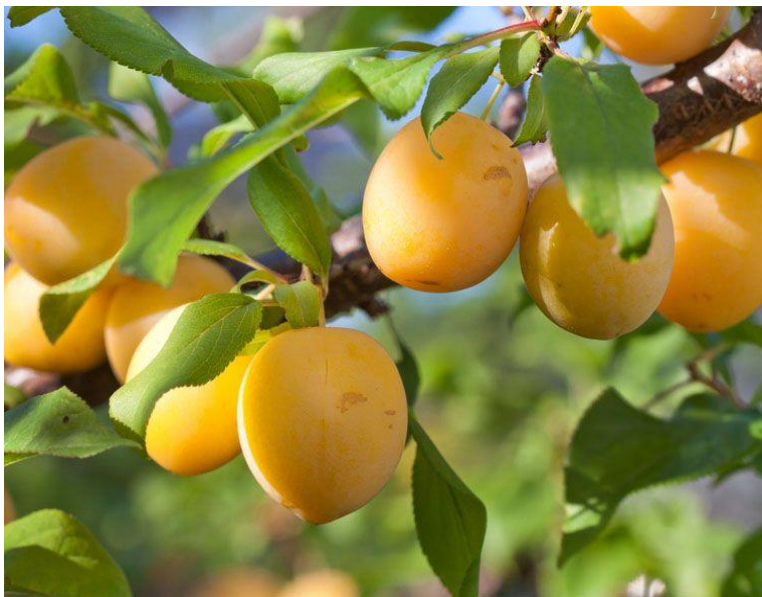

Figure 2: Plum cultivar of Bellamira

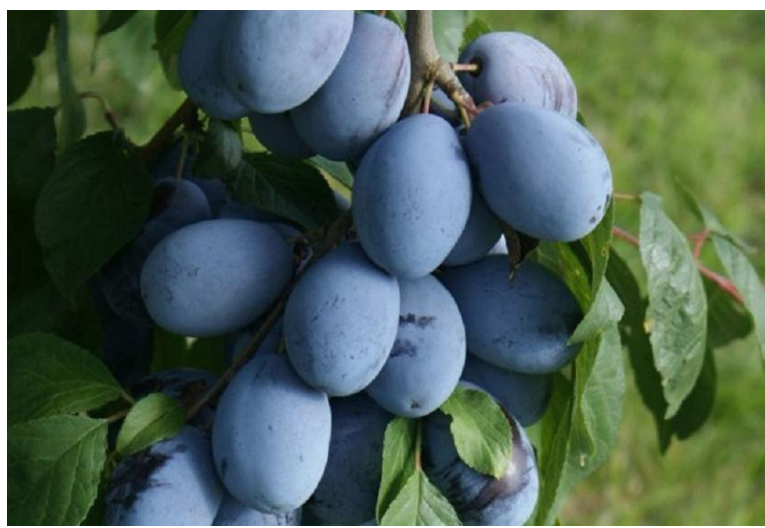

Figure 4: Plum cultivar of Presenta

\section{References}

Artevos GmbH Fruit cultivars (Technical paper). Freiburg.

Faust, M. (1989): Physiology of temperate zone fruit trees. John Wiley and Sons, New York - Chichester-BrisbaneToronto-Singapore. p. 183-186.

Kovács, Sz. (2013): Examination of the adaptation of German plum varieties in Hungary.Hungarian Agricultural Research 22 (2): 4-11. (ISSN 1216-4526)

Makovics-Zsohár, N., Tóth, M., Surányi, D., Kovács, Sz., Hegedüs, A., Halász, J. (2017): Simple sequence repeat markers reveal Hungarian plums (Prunus domestica L.) germplasm as a valuable gene resource. HortSci. 52 (12): 1655-1660.

Molnár, Á. M., Ladányi, M., Kovács, Sz. (2014): Magyar és német szilvafajták (Prunus domestica L.) gyümölcsminőségének értékelése érzékszervi bírálattal és laboratóriumi vizsgálatokkal. Kertgazdaság. 46 (3): 8-16.

Molnár, Á. M., Ladányi, M., Kovács, Sz. (2016): Evaluation of the production traitsand fruit quality of German plum cultivars. Acta Univ. Agric. et Silvicult. Mendelianae Brunensis 64: 109-114.

Nádosy, F. (2016): Az újabb német és szerb szilvafajták szerepe a magyarországi termesztésben. http://www.cefrucht.hu/akt/tiny_files/pdf/dr_nadosy_ferenc_20 160901.pdf 
Surányi, D. (1976): Differentiation of self-fertility and self sterility in Prunus by stamen number/pistil length ratio. HortSci 11: 406-407.

Surányi, D. (1985): Gyüjteményes és termesztett szilvafajták virágszerkezete, alaktani bélyegek és az öntermékenyülés kapcsolata. Kandidátusi értekezés (kézirat). MTA, Budapest.

Surányi, D. (1991): A fajta, az alany és a környezet jelentősége a szilvatermesztés fejlesztésében. Akadémiai doktori értekezés (kézirat). MTA, Budapest.

Surányi, D. (2004): Onthogenetic characteristics on flowers of some plums. Part II. Acta Hort. 359: 278-286.
Surányi, D. (2009): Lépcsőfokok. Értekezések a gyümölcstermesztés köréből. Akcident Kft., Cegléd.

Surányi, D. (2019): Szilvafajták leírása (in press). Magyarország kultúrflórája 78. köt. A házi szilva Prunus domestica L. szerk. Surányi D. - és írta többek közremüködésével. SZIE Könyvkiadó, Gödöllö-Budapest.

Tóth, E. (1957): Élet- és alaktani összehasonlító vizsgálatok szilvajtákon. Kert. Kut. Int. Évk.2: 11-129

Tóth, E. (1969): Szilvafajták öntermékenyülési vizsgálata. Doktori értekezés (kézirat). Kert. Egyetem, Budapest.

http://www.omafra.gov.on.ca/english/crops/facts/07-039.htm Plum Cultivars - European and Japanese. 